DOI https://doi.org/10.30525/978-9934-588-80-8-2.58

\title{
INFLUENCE OF MEDIA TECHNOLOGIES ON THE FORMATION OF FUTURE PRIMARY SCHOOL TEACHERS' READINESS FOR PROFESSIONAL COMMUNICATION IN A FOREIGN LANGUAGE
}

\author{
Popova L. M. \\ Senior Lecturer at the Department of Foreign Languages \\ and Teaching Methods \\ Drahomanov National Pedagogical University \\ Kyiv, Ukraine
}

The article deals with the problems of formation of future primary school teachers' readiness for professional communication in a foreign language. But according to the English Proficiency Index (IF), Ukraine ranks 49th out of 100 countries in terms of English language proficiency, demonstrating a low level of practical skills [1]. The importance of this problem is the fact that the development of communication skills determines the successful implementation of the educational motives. The new standards are based on the Recommendations of the European Parliament and of the European Council, on key competencies for lifelong learning (18 December 2006). The four-dimensional model of education The United Nations Educational, Scientific and Cultural Organization (UNESCO) has proposed a conceptual model for the development of educational programs. The model has four dimensions of learning: learn to know (learn); learn to apply knowledge (act); learn to be (live in harmony with oneself) learn to live together (live in peace and harmony with others) [5]. And the SAMR (Substitution, Augmentation, Modification, Redefinition) model developed by R. Puentedura will help to assess the extent to which the use of technology contributes (or not) to improving the level of learning. Planning work on the system of Paul Mayer S.M.A.R.T. (specific, measurable. achievable, relevant, time-based) is focused on the final result.

According to the concept of the New Ukrainian School, the most successful professionals in the labor market are going to be those, who will be able to learn through life, set and achieve professional goals, think critically, work in a team, have skills of communication in multicultural environment. One of the priority areas of for the future elementary school teachers' preparation is the urgent need to master a foreign language at a sufficient level and be ready to navigate the territory of the modern media space. The use of the Information and Communication Technology (ICT), in 
the educational process and management of educational institutions and the educational system should become a tool to ensure success of the New Ukrainian School. It will significantly expand pedagogue's capabilities and optimize management processes, instilling technology competencies important to our century, in pupils. Adaptation of modern media to the educational process significantly changes the role of the teacher and the educational process itself, its methods and content, the ability to solve on a mass scale a certain type of tasks aimed at reflecting and self-regulation of the student youth of their educational activity. Nowadays in teaching and learning communication skills, we have a lot to choose from the world of technology: Audio Cassettes, Blogs, C.A.L.L., CD Rom, Computers, Electronic Dictionary, Email, the Internet, and Power Point, TV, Videos or DVD's. The last two decades have witnessed a revolution due to onset of technology, and has changed the dynamics of educational institutes, and has also influenced the educational system and the way people interact and work in the society. This rapid rising and development of information technology has offered a better pattern to explore the new teaching model.

Using multimedia to create a context to teach communication skill has its unique advantages. Nowadays technology plays a very important role in teaching communication skills. Researcher S. Aufennager describes three possible options for responding to the demands of the media education system of the future: the first is a conservative option; the second proceeds from the idea of integration, but considers it in the aspect of assimilation in traditional methodological and didactic approaches; the third one is intended to show how integration of new media technologies into education in pedagogical support can be carried out, and that in the process of competition with the media market the educational system should be more critical in its consideration.

Pedagogy of partnership is based on communication, cooperation and collaboration between the teacher, the pupil, and the parents. The further development of civilization depends on how the relationship between the media and the individual, media and culture, media and education will be built. For the development of communicative skills of future primary school teachers, which are formed on the basis of language skills, abilities, knowledge and communicative competence, the latest teaching methods are used, which combine cognitive and communicative goals. Innovative methods of learning foreign languages contribute to the development and self-improvement of the individual, and the disclosure of its creative potential [4].

The main task of media education can be formulated as follows: nonformal education of a person, in which a person, without receiving any certificates, can improve their educational level, receive information from various fields of knowledge; it ensures the full inclusion of a person in the 220 
system of communications in the process of mass communication. Media pedagogy should teach a person to select this information. It helps to increase the effectiveness of media education, as it develops communication skills with information media, information competence and the ability to select information. A person uneducated in the field of mass media and communication is more subject to manipulation of the mass media because he: does not fully perceive a significant part of information, especially audiovisual, because it is simply not prepared for its perception; does not fully understand the essence of the message or does not clearly understand what may have several meanings; takes a passive position on the media, does not know how to protect themselves from their influence and often does not realize that such protection is necessary.

In addition, without media education, a person is unfamiliar with many forms of self-expression and communication with other people. Hence, the generalized tasks of media education can be expressed as follows: to gain a conscious experience of nonverbal perception, to comprehensively develop their perceptual abilities; master the languages of non-verbal messages that will allow a person to better understand their content and pictorial capabilities; to develop mechanisms for establishing a «psychological distance» between it and the media, psychological protection against manipulation of its consciousness, acquiring skills of critical evaluation of information and developing in it the desire to influence the activities of the media.

Having studied modern innovative technologies in the study of foreign languages of future primary school teachers to intercultural professional communication, we can conclude that the effectiveness of their study is achieved through a successful combination of modern methods and the use of innovative educational technologies. The modern education system has to be aimed at training future specialists not for passive accumulation of information and experience, but to form his requirement and ability to think, and to think independently and creatively; and special relevance is gained by development of the abilities allowing to find optimum solutions at uncertainty of conditions and diversity of answers [2].

The main advantages of using media technologies on the formation of future primary school teachers' readiness for professional communication in a foreign language include encouraging and motivating students, eliminating the fear of mistakes, overcoming the fear of language barriers, involving each student in work, using acquired prior to the experience, a studentcentered environment.

In the organization of creative communicative activity important reference points are the communication purposes:

- establishment of contacts between participants of dialogue;

- exchange of messages, opinions, plans, decisions; 
- motivation of the activity of the partner in communication directed on performance of mutually advantageous actions;

- coordination of the organization of joint activity;

- understanding of sense of intentions, installations of the partner in communication;

- influence on emotions, intentions, decisions, opinions;

- establishment of the relations in system of business communication;

- belief and partner's over persuasion;

- resolution of conflicts [3].

Thus, the specification of scientific ideas of the maintenance of communicative creativity of future primary school teachers, development of its diagnostics, identification of the corresponding pedagogical conditions and design of effective technology of their creation is required. All this will promote assimilation of fundamental components of professional education - an important component in system of training of future primary school teachers, the phenomena of the versatile and demanding studying of both internal, and external aspects of differences in communication in a foreign language.

\section{References:}

1. English Proficiency Index https://www.ef.com/wwen/epi

2. Mateer G. Dirk.Using Media to Enhance Teaching and Learning Online Article Directory Website: https://serc.carleton.edu/sp/library/media/ index.html

3. Patel, Chirag. Use of Multimedia Technology in Teaching and Learning communication skill: An Analysis. Online Article Directory Website: http://www.ijoart.org/docs/Use-of-MultimediaTechnology-in-Teaching-and-Learning-communication-skill.pdf

4. Niyazova G., Bekbulatova I., Kerimbaeva B., Abdullina G. The methodology of the formation of the communicative orientation of the «English» course by means of information and telecommunication technologies (itt) in the institutions of higher education. Journal of Language and Literature, Vol. 6. No. 4. November, 2015. Pp. 351-354.

5. Popova Liudmila. Formation of the preparation of future primary school teachers for intercultural professional communication by the means of innovative educational technologies // Research and Innovation: Collection of scientific articles. - Yunona Publishing, New York, USA, 2020. 216 p. Pp. $196-200$. 